\title{
Evaluasi Perubahan Iklim dan Pengaruhnya terhadap Pola Tanam, Waktu Tanam serta Produktivitas Kedelai (Glycine max L. Merrill) di Kabupaten Malang Jawa Timur
}

\author{
The Evaluation of Climate Change and the Effect to Cropping Pattern, Panting Season and \\ Productivity of Soybean (Glycine max L. Merrill) in Malang Regency, East Java \\ Ninuk Herlina $\left.{ }^{1 *}\right)$, S Fajriani ${ }^{1}$, F A Rahman ${ }^{1}$ \\ ${ }^{1}$ Jurusan Budidaya Pertanian, Fakultas Pertanian, Universitas Brawijaya, \\ Malang, Jawa Timur 65145 \\ ${ }^{*}$ Penulis untuk korespondensi: ninukherlinaid@gmail.com
}

\begin{abstract}
Climate change is a negative impact due to development activities on Earth. The lose function forests can cause degradation and escalation of greenhouse gas concentrations that cause global warming and trigger climate change. Climate change is suspected affect the cropping pattern, planting time and soybean productivity. The purpose of the study was to evaluate the expected climate change and analyze correlation between climatic elements, the pattern and time of planting, and soybean productivity. The research was carried out on March to April 2018 in Kalipare, Donomulyo, Singosari and Dau, Malang Regency, East Java. The research methods were field interview by using a questionnaire. The materials are the climate elements, soybean productivity and interview data. Total respondents were 40 farmers. Climate change was analyzed by analyzing mean changes in temperature, rainfall and number of rainy days in period 1 (1988-1997), period 2 (1998-2007) and period 3 (2008-2017). Correlation coefficient analysis was used to determine the correlation between climate elements and soybean productivity and followed by t-test. The results show that climate change has been occurred in Malang Regency for the past 30 years. The correlation between temperatures, rainfall and soybean productivity has "low" correlation, while number of rainy days and soybean productivity has a "very low" correlation. Temperature significantly affected soybean productivity in Malang Regency. Soybean cropping patterns are not affected by climate change, but planting time is influenced by shifting seasons.
\end{abstract}

Keywords: climate Change, Correlation, Cropping Patterns, Planting Time, Rainfall, Rainy Days, Soybean Productivity, Temperature

\begin{abstract}
ABSTRAK
Perubahan iklim merupakan dampak negatif akibat kegiatan pembangunan di Bumi. Hutan yang kehilangan fungsi akibat terdegradasi serta kenaikan konsentrasi gas rumah kaca menyebabkan pemanasan global dan memicu terjadinya perubahan iklim. Perubahan iklim diduga berpengaruh pada pola tanam, waktu tanam dan produktivitas kedelai di Kabupaten Malang. Tujuan penelitian adalah untuk mengevaluasi perubahan iklim yang diduga telah terjadi dan menganalisis hubungan antara unsur iklim dengan pola tanam, waktu tanam serta produktivitas kedelai. Penelitian dilaksanakan mulai bulan Maret - April 2018 di Kecamatan Kalipare, Donomulyo, Singosari dan Dau Kabupaten Malang, Jawa Timur. Alat yang digunakan yaitu kuisioner. Bahan yang digunakan yaitu data unsur iklim dan produktivitas kedelai Kabupaten Malang tahun 1988-2017) dan hasil wawancara
\end{abstract}


dengan petani kedelai. Penelitian menggunakan metode survey dengan total responden sebanyak 40 petani. Analisis perubahan iklim dilakukan dengan menganalisis perubahan rerata suhu, curah hujan dan jumlah hari hujan pada periode 1 (1988-1997), periode 2 (1998-2007) dan periode 3 (2008-2017). Analisis koefisien korelasi digunakan untuk mengetahui hubungan antara unsur iklim dan produktivitas kedelai dan dilanjutkan dengan uji t. Hasil penelitian menunjukkan bahwa perubahan iklim telah terjadi di Kabupaten Malang selama 30 tahun terakhir. Korelasi antara suhu, curah hujan dengan produktivitas kedelai memiliki hubungan "rendah", sedangkan jumlah hari hujan dengan produktivitas kedelai memiliki hubungan "sangat rendah". Suhu berpengaruh nyata terhadap produktivitas kedelai Kabupaten Malang. Pola tanam kedelai tidak dipengaruhi oleh perubahan iklim, namun waktu tanam kedelai dipengaruhi oleh pergeseran musim.

Kata kunci: curah Hujan, Hari Hujan, Korelasi, Perubahan Iklim, Pola Tanam, Produktivitas Kedelai, Suhu, Waktu Tanam

\section{PENDAHULUAN}

Perubahan iklim global merupakan dampak negatif yang timbul akibat kegiatan pembangunan di berbagai belahan dunia. Hutan dunia yang semakin berkurang dan rusak (Pawitro, 2016) serta konsentrasi CO dan $\mathrm{CO}_{2}$ yang terus meningkat di lapisan atmosfer bumi (Ramlan, 2002) memicu terjadinya efek pemanasan global. Pemanasan global yang terjadi akan diikuti dengan perubahan iklim yang ditandai dengan adanya penyimpangan nilai unsur iklim (Febrianti, 2018). Negara di berbagai belahan dunia, seperti Indonesia diketahui terus mengalami kehilangan tutupan hutan. Data terakhir deforestrasi Indonesia periode 2006-2009 menghasilkan angka deforestrasi sebesar 0,83 juta ha.tahun ${ }^{-1}$ (Meridian et al., 2015).

Laporan Fourth Assessment of IPCC tahun 2007 dalam Tosiani (2015) menyebutkan bahwa telah terjadi kenaikan konsentrasi gas rumah kaca sebesar $70 \%$ dari tahun 1974 hingga 2005. Hutan yang kehilangan fungsinya akibat terdegradasi serta kenaikan konsentrasi gas rumah kaca terus terjadi dapat menyebabkan efek pemanasan global semakin meningkat (Ramlan, 2002) dan memicu terjadinya perubahan iklim yang ekstrim (Utina, 2015). Perubahan iklim yang ekstrim dapat dikenali dari kejadian curah hujan yang menurun drastis pada lokasi tertentu dan meningkat drastris di lokasi lainnya (Laimeheriwa, 2014).
Perubahan iklim merupakan fenomena alam yang terjadi akibat adanya perubahan nilai atau kondisi beberapa unsur iklim yang magnitude atau intensitasnya cenderung berubah serta menyimpang dari dinamika dan kondisi rata-rata menuju ke arah tertentu (meningkat atau menurun) (Hermanto, 2011), baik yang terjadi secara alamiah maupun yang dapat terjadi lebih cepat akibat aktivitas manusia (Nurdin, 2012). Indonesia dalam 30 tahun terakhir telah terjadi beberapa kali kondisi iklim ekstrim yang ditandai dengan frekuensi variabilitas iklim yang semakin tinggi (Apriyana et al., 2016). Telah terjadi perubahan iklim di Indonesia, seperti terjadi peningkatan jumlah curah hujan dan suhu di Wilayah Timur serta terjadi penurunan curah hujan dan peningkatan suhu di Wilayah Barat Indonesia (Syambuddin, et al. (2004) dalam Ruminta (2015).

Perubahan iklim merupakan salah satu faktor dapat mempengaruhi produktivitas sektor pertanian, termasuk berdampak pada menurunnya produksi dan produktivitas komoditas pangan (Soeparno et al., 2013). Produktivitas kedelai di Kabupaten Malang pada tiga dekade terakhir (1988-2017) menunjukkan perkembangan yang fluktuatif (Anonymous, 2016).

Perubahan iklim tidak hanya berpengaruh terhadap produktivitas tetapi juga diduga berpengaruh terhadap pola tanam tanaman kedelai. Pola tanam merupakan istilah yang identik dengan awal 
musim tanam suatu jenis tanaman. Awal musim tanam kedelai ditentukan berdasarkan pada neraca air lahan dasarian untuk mengetahui bulan basah dan bulan kering. Pemilihan waktu tanam tersebut dilakukan untuk menghindari resiko kegagalan panen kedelai yang tinggi (Sipayung, 2005).

Produksi serta produktivitas kedelai yang terganggu serta perubahan pola tanam yang terjadi akibat perubahan iklim selanjutnya dapat mempengaruhi ketersediaan kedelai di Indonesia. Informasi mengenai perubahan iklim yang diduga telah terjadi serta faktor perubahan iklim yang diduga mempengaruhi fluktuasi produktivitas dan pola tanam kedelai di Kabupaten Malang selama 30 tahun terakhir tersebut perlu dipelajari. Penelitian ini bertujuan untuk mengevaluasi perubahan iklim yang diduga telah terjadi dan menganalisis hubungan antara unsur iklim dengan pola tanam, waktu tanam serta produktivitas kedelai.

\section{BAHAN DAN METODE}

Penelitian dilaksanakan mulai bulan Maret hingga April 2018 di Kecamatan Kalipare, Donomulyo, Singosari dan Dau, Kabupaten Malang, Jawa Timur. Alat yang digunakan adalah kuisioner dan bahan yang digunakan terdiri dari data primer merupakan hasil wawancara terhadap 40 petani kedelai dan data sekunder yang meliputi (1) data produksi kedelai Kabupaten Malang tahun 1988-2017 (2) data unsur iklim (curah hujan, suhu dan kelembaban udara) tahun 1988-2017.

Metode penelitian yang digunakan adalah metode survei, yaitu penelitian dengan cara mengumpulkan data dari sampel yang dapat mewakili seluruh populasi dengan menggunakan kuisioner sebagai alat pengumpulan data yang pokok. Jenis data digunakan dalam penelitian yaitu data primer dan data sekunder.

Metode penentuan lokasi penelitian menggunakan metode purposif sampel (Purposive Sampling). Pemilihan kecamatan yang dijadikan sebagai sampel didasarkan atas kontinuitas penanaman kedelai. Petani yang dijadikan sebagai responden dalam penelitian ini berjumlah 40 orang yang tersebar di empat kecamatan terpilih yaitu Kecamatan Kalipare dan Pagak (Kabupaten Malang bagian Selatan) serta Kecamatan Singosari dan Dau (Kabupaten Malang bagian Utara). Pengumpulan data sekunder meliputi : (1) data iklim (suhu, curah hujan dan hari hujan harian) Kabupaten Malang tahun 19882017 yang diperoleh dari BMKG Stasiun Geofisika Karangkates dan Stasiun Klimatologi Karangploso, Kabupaten Malang dan (2) data produksi tahunan kedelai Kabupaten Malang periode 19882017 yang diperoleh dari Situs Resmi Kementerian Pertanian Republik Indonesia.

Analisis perubahan iklim dilakukan dengan: (1) membandingkan rerata suhu, curah hujan dan jumlah hari hujan bulanan dan tahunan periode 1 (1988-1997), periode 2 (1998-2007) dan periode 3 (2008-2017) dengan dengan rerata suhu, curah hujan dan jumlah hari hujan bulanan dan tahunan selama 30 tahun terakhir dan (2) menganalisis pergeseran awal musim hujan dan musim kemarau selama 30 tahun terakhir untuk menganalisis pergeseran waktu tanam kedelai di Kabupaten Malang. Analisis pergeseran awal musim hujan $(\mathrm{AMH})$ dan awal musim kemarau (AMK) dilakukan dengan sistem dasarian Setyawardhana dan Susandi (2015) menjelaskan bahwa kriteria AMH di Indonesia menurut BMKG adalah berdasarkan curah hujan dasarian dimana musim hujan ditetapkan apabila jumlah curah hujan lebih dari atau sama dengan 50 mm pada satu dasarian, dan diikuti dua dasarian berikutnya. Begitupun pada AMK, namun penetapan AMK adalah jika jumlah curah hujan kurang dari $50 \mathrm{~mm}$. Analisis keeratan hubungan unsure iklim dengan produktivitas kedelai dengan analisis kuantitatif analisis koefisien korelasi sederhana (Koefisien Korelasi Product Moment/Koefisien Korelasi Pearson) dan jika korelasi antara unsur-unsur iklim 
dengan produktivitas kuat/tinggi maka akan dilanjutkan dengan Analisis Regresi Linear Sederhana. Analisis kuantitatif secara keseluruhan tersebut dilakukan dengan menggunakan Aplikasi SPSS 16 dan Software Microsoft Excel 2010.

Analisis pengaruh perubahan iklim terhadap pola tanam kedelai dilakukan pada dua hal yang berkaitan dengan pola tanam yaitu (1) susunan tata urutan tanam (waktu tanam) dilakukan berdasarkan pada pergeseran awal musim hujan yang terjadi selama 30 tahun terakhir dan (2) tata letak tanam kedelai di Kabupaten Malang, dilakukan berdasarkan pada informasi yang diperoleh langsung dari 40 petani sebagai responden.

\section{HASIL}

\section{Produktivitas Kedelai}

Produktivitas serta perkembangan produktivitas kedelai di Kabupaten Malang selama 30 tahun (1988-2017) ( Tabel 1).

Tabel 1. Produktivitas kedelai kabupaten malang tahun 1988-2017 (dinas pertanian dan perkebunan kabupaten malang, 2018).

\begin{tabular}{|c|c|c|c|c|c|}
\hline Tahun & $\begin{array}{l}\text { Produktivitas } \\
\left(\text { ton. }^{-1} \mathrm{~h}^{-1}\right)\end{array}$ & $\begin{array}{c}\text { Perubahan } \\
\text { Produktivitas } \\
\left(\text { ton.ha }^{-1}\right)\end{array}$ & Tahun & $\begin{array}{l}\text { Produktivitas } \\
\quad\left(\text { ton. }^{-1} \mathrm{a}^{-1}\right)\end{array}$ & $\begin{array}{c}\text { Perubahan } \\
\text { Produktivitas } \\
\left(\text { ton.ha }^{-1}\right)\end{array}$ \\
\hline 1988 & 0,81 & $-0,28$ & 2003 & 0,75 & $-0,34$ \\
\hline 1989 & 0,79 & $-0,30$ & 2004 & 0,75 & $-0,34$ \\
\hline 1990 & 1,08 & - 0,01 & 2005 & 0,78 & $-0,31$ \\
\hline 1991 & 1,14 & $+0,05$ & 2006 & 0,89 & $-0,20$ \\
\hline 1992 & 0,75 & $-0,34$ & 2007 & 1,09 & 0,00 \\
\hline 1993 & 1,05 & $-0,04$ & 2008 & 1,13 & $+0,04$ \\
\hline 1994 & 1,09 & 0,00 & 2009 & 1,17 & $+0,08$ \\
\hline 1995 & 1,19 & $+0,10$ & 2010 & 1,17 & 0,08 \\
\hline 1996 & 1,43 & $+0,24$ & 2011 & 1,24 & $+0,15$ \\
\hline 1997 & 1,52 & $+0,43$ & 2012 & 1,19 & $+0,10$ \\
\hline 1998 & 0,89 & $-0,20$ & 2013 & 1,05 & $-0,04$ \\
\hline 1999 & 1,49 & $+0,40$ & 2014 & 1,16 & $+0,07$ \\
\hline 2000 & 1,26 & $+0,17$ & 2015 & 0,75 & $-0,34$ \\
\hline 2001 & 0,71 & $-0,38$ & 2016 & 1,39 & $+0,30$ \\
\hline 2002 & 1,40 & $+0,31$ & 2017 & 1,61 & $+0,52$ \\
\hline Jumlah & & 32,72 & & & \\
\hline Rerata & & 1,09 & & & \\
\hline
\end{tabular}

Keterangan : (+) peningkatan produktivitas, (-) penurunan produktivitas

\section{Evaluasi Perubahan Iklim Kabupaten Malang}

Rerata suhu bulanan di Kabupaten Malang bagian Utara pada periode 1 menurun $0,39{ }^{\circ} \mathrm{C}$ dari nilai rerata selama 30 tahun terakhir, sedangkan pada periode 2 dan 3 meningkat 0,08 dan $0,31^{\circ} \mathrm{C}$ (Gambar 1). Di Kabupaten Malang bagian Selatan rerata suhu bulanan pada periode 1 menurun $0,23{ }^{\circ} \mathrm{C}$, sedangkan pada periode 2 dan 3 meningkat 0,21 dan $0,03{ }^{\circ} \mathrm{C}$ (Gambar 2).

Rerata suhu tahunan pada periode 1 menurun $0,31{ }^{\circ} \mathrm{C}$ dari nilai rerata selama 30 tahun terakhir, sedangkan pada periode 2 dan 3 meningkat 0,15 dan $0,17^{\circ} \mathrm{C}$. Rerata suhu tahunan pada periode 1 menurun 0,31 ${ }^{\circ} \mathrm{C}$ dari nilai rerata selama 30 tahun terakhir, sedangkan pada periode 2 dan 3 meningkat 0,04 dan $0,27{ }^{\circ} \mathrm{C}$. Rerata suhu tahunan pada periode 1 menurun $0,26{ }^{\circ} \mathrm{C}$ dari nilai rerata selama 30 tahun terakhir, sedangkan pada periode 2 dan 3 meningkat 0,22 dan 0,05 ${ }^{\circ} \mathrm{C}$. Rerata suhu tahunan pada periode 1 menurun $0,28{ }^{\circ} \mathrm{C}$ dari nilai rerata suhu bulanan selama 30 tahun terakhir, sedangkan pada periode 2 dan 3 meningkat 0,13 dan $0,15^{\circ} \mathrm{C}$ (Gambar 3). 


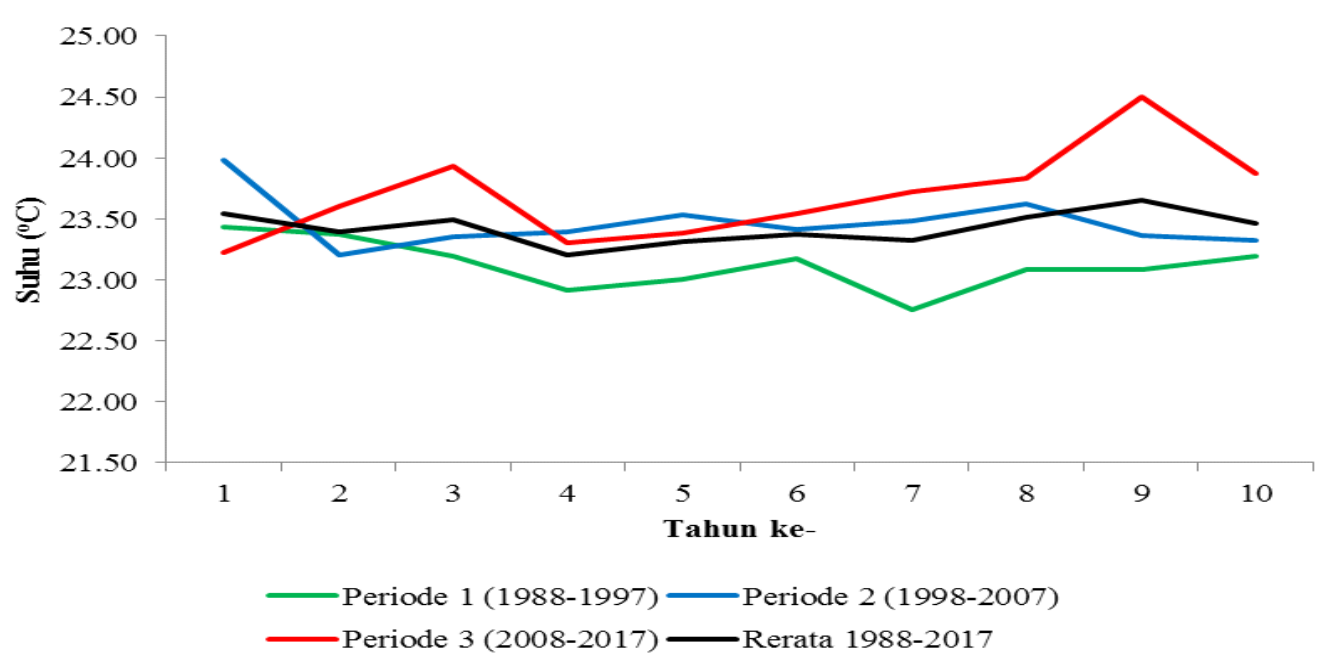

Gambar 1. Rerata suhu tahunan kabupaten malang bagian utara selama 30 tahun

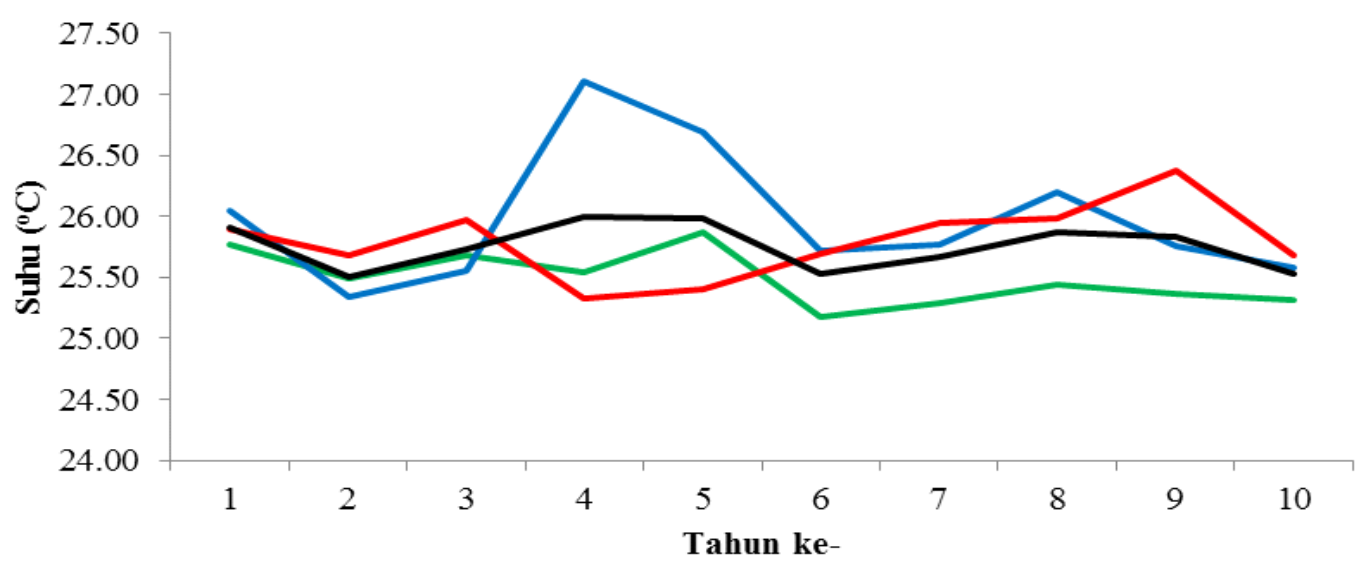

— Periode 1 (1988-1997) — Periode 2 (1998-2007)

—Periode 3 (2008-2017) — Rerata 1988-2017

Gambar 2. Rerata suhu tahunan kabupaten malang bagian selatan selama 30 tahun

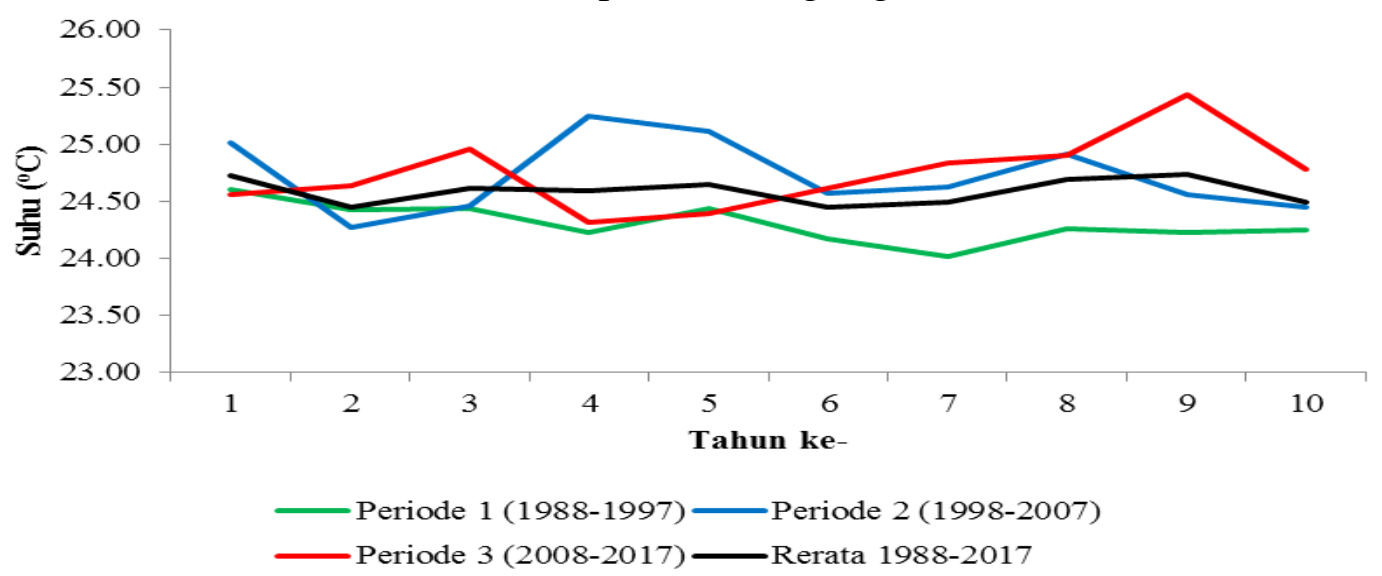

Gambar 3. Rerata suhu tahunan kabupaten malang selama 30 tahun

Rerata curah hujan bulanan Rerata curah hujan bulanan Kabupaten Kabupaten Malang bagian Utara pada Malang bagian Selatan pada periode 1 periode 1 dan 3 meningkat 0,5 dan $5,0 \mathrm{~mm}$ menurun $22,1 \mathrm{~mm}$ dari nilai rerata selama dari nilai rerata selama 30 tahun terakhir, 30 tahun, sedangkan pada periode 2 dan 3 sedangkan pada periode 2 menurun 5,5 mm. meningkat 17,5 dan 4,6 mm. 
Rerata curah hujan tahunan Kabupaten Malang bagian Utara pada periode 1 menurun $10,79 \mathrm{~mm}$ dari nilai rerata selama 30 tahun terakhir, sedangkan pada periode 2 dan 3 meningkat 5,97 dan 4,83 mm. Rerata curah hujan tahunan Kabupaten Malang bagian Selatan pada periode 1 menurun $265 \mathrm{~mm}$ dari nilai rerata selama 30 tahun terakhir, sedangkan pada periode 2 dan 3 meningkat 209,50 dan $55,49 \mathrm{~mm}$. Rerata curah hujan tahunan pada periode 1 menurun $131,09 \mathrm{~mm}$, sedangkan pada periode 2 dan 3 meningkat 72,92 dan $58,17 \mathrm{~mm}$ dari nilai rerata selama 30 tahun terakhir (Gambar 4).

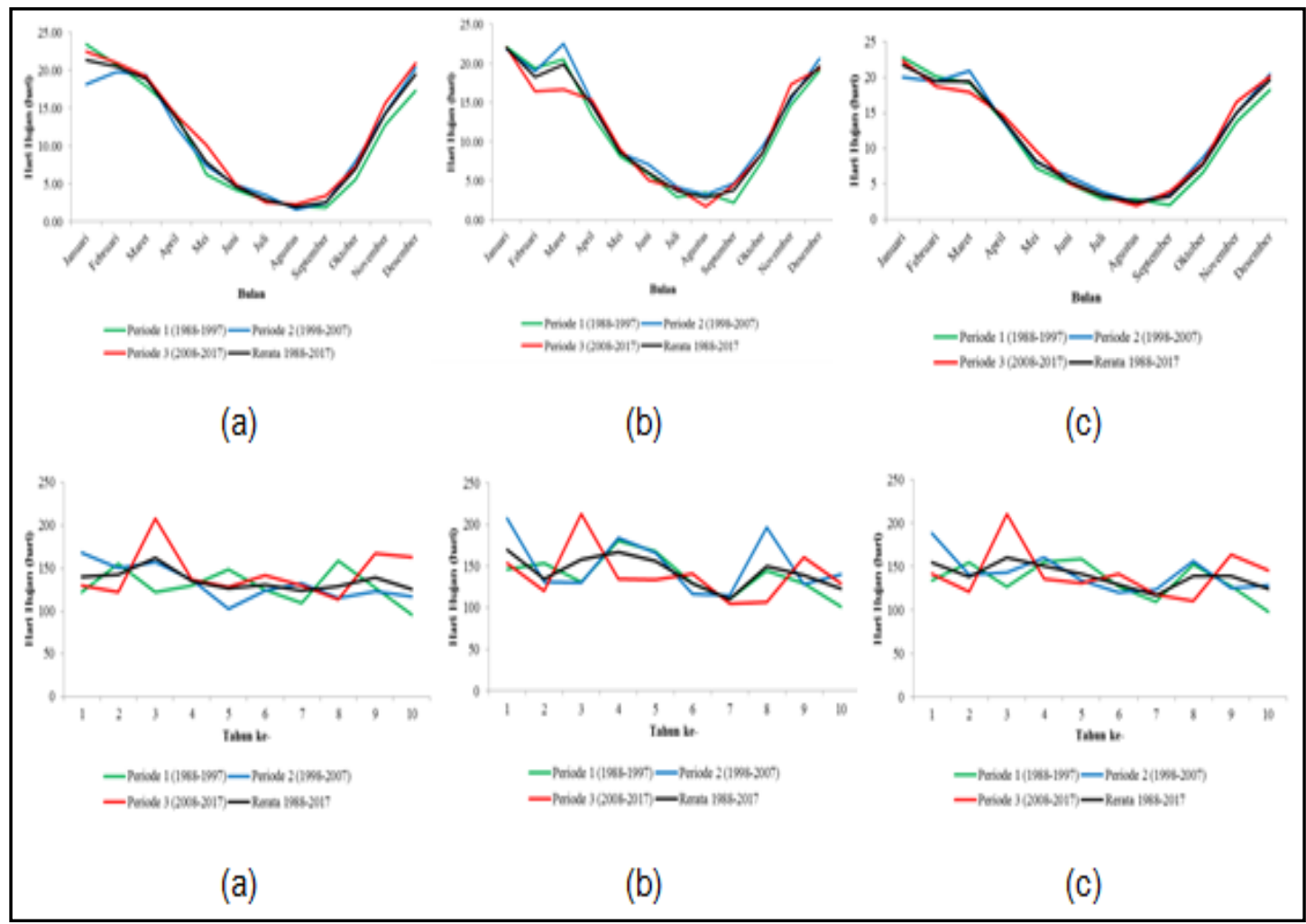

Gambar 4. Rerata hari hujan bulanan/tahunan kabupaten malang bagian (a) utara, (b) selatan, (c) umum.

Jumlah hari hujan bulanan Kabupaten Malang bagian Utara pada periode 1 dan 2 tidak terjadi penyimpangan dari rerata selama 30 tahun terakhir, sedangkan pada periode 3 hari hujan meningkat 1 hari. Rerata jumlah hari hujan bulanan Kabupaten Malang bagian Selatan pada periode 1 dan 3 tidak terjadi penyimpangan, sedangkan jumlah hari hujan pada periode 2 meningkat 1 hari. Rerata jumlah hari hujan bulanan Kabupaten Malang pada periode 2 dan 3 tidak terjadi penyimpangan, pada periode 1 yang menurun sebesar 1 hari (Gambar 5).
Penyimpangan rerata jumlah hari hujan tahunan Kabupaten Malang bagian Utara pada periode 1 dan 2 dari rerata selama 30 tahun terakhir menurun sebesar 6 dan 3 hari, sedangkan pada periode 3 meningkat 9 hari. Jumlah hari hujan tahunan Kabupaten Malang bagian Selatan pada periode 1 dan 3 menurun masingmasing 4 hari, pada periode 2 meningkat 8 hari. Rerata jumlah hari hujan tahunan Kabupaten Malang pada periode 1 menurun 5 hari, sedangkan pada periode 2 dan 3 masing-masing meningkat 3 hari. 


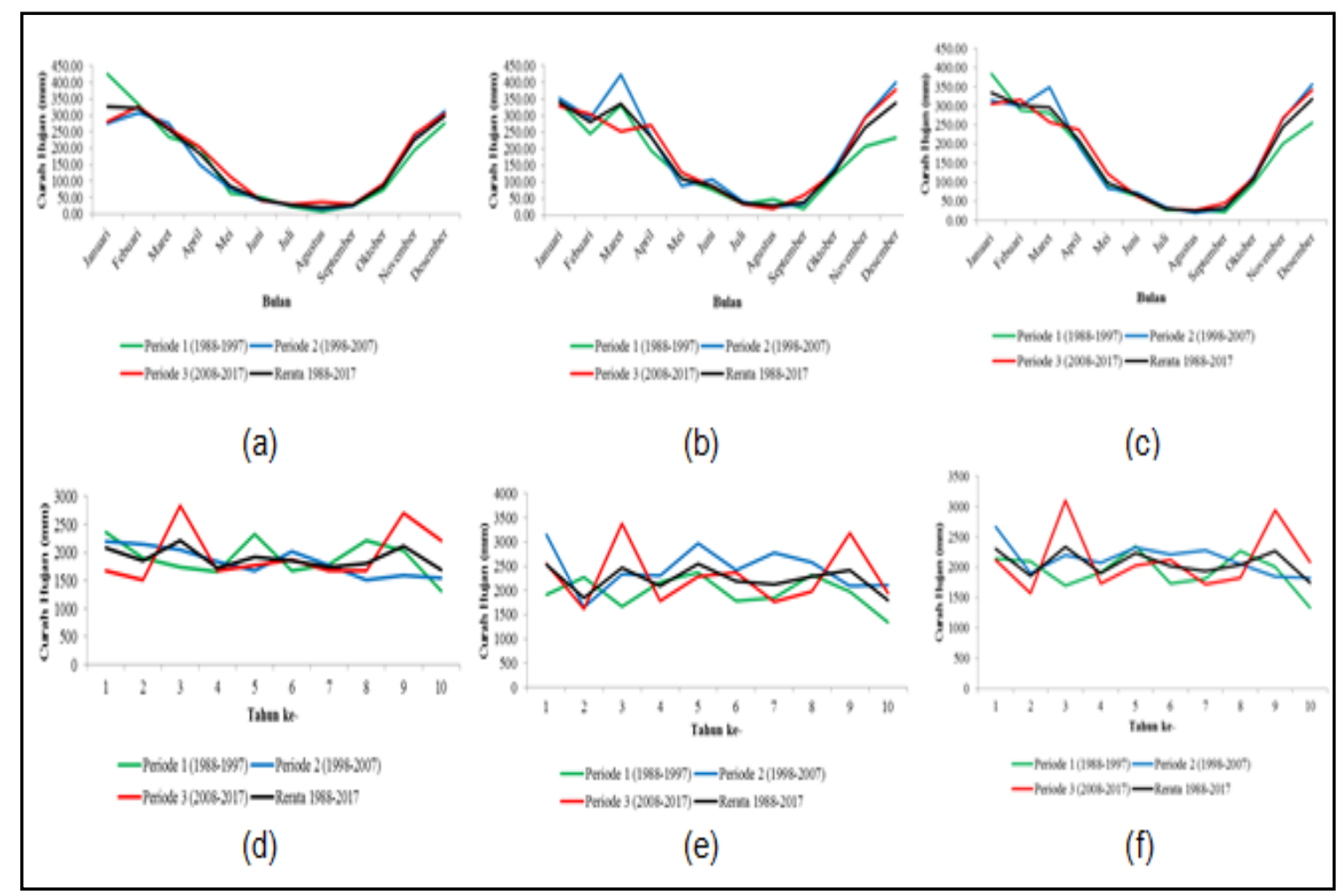

Gambar 5. Rerata curah hujan bulanan/tahunan kabupaten malang bagian (a) utara, (b) selatan, (c) umum.

\section{Uji Korelasi Unsur Iklim terhadap}

Produktivitas Kedelai

Curah hujan memiliki keeratan hubungan yang "sangat rendah" terhadap produktivitas kedelai $(r=-0,18)$, sedangkan hari hujan dan suhu memiliki keeratan hubungan yang "rendah" $(r=-0,21$ dan $r=$ -0,31). Suhu berpengaruh nyata terhadap produktivitas kedelai, sedangkan curah hujan dan hari hujan berpengaruh tidak nyata terhadap produktivitas kedelai (Tabel 2).

Tabel 2. Hasil uji korelasi antara unsur iklim dengan produktivitas kedelai selama 30 tahun terakhir (1988-2017)

$\begin{array}{lcccc}\text { Variabel } & \begin{array}{c}\text { Curah Hujan } \\ (\mathrm{mm})\end{array} & \begin{array}{c}\text { Hari Hujan } \\ (\text { hari) }\end{array} & \begin{array}{c}\text { Suhu } \\ \left({ }^{\circ} \mathrm{C}\right)\end{array} & \left.\begin{array}{c}\text { Produktivitas } \\ (\text { ton.ha }\end{array}{ }^{-1}\right)\end{array}$

Curah Hujan (mm)

Hari Hujan (hari)

Suhu $\left({ }^{\circ} \mathrm{C}\right)$

Produktivitas (ton.ha ${ }^{-1}$ ) 1

Keterangan : Hubungan nyata pada taraf 5\% (t Tabel $=1,70 \&-1,70 ; \mathrm{t}$ hitung curah hujan $=-0,97 ; \mathrm{t}$ hitung jumlah hari hujan $=-1,13 ; \mathrm{t}$ hitung suhu $=-1,72 *$ ) memiliki hubungan yang nyata dengan nilai: $t$ hitung $>t$ tabel.

\section{Analisis Pola Tanam Kedelai}

Pola tanam kedelai di kabupaten malang terdapat perbedaan dominasi yang diterapkan antara petani di Kabupaten Malang bagian Utara dan Selatan (Tabel 3).
Petani Kabupaten Malang bagian Utara dominan menerapkan pola tanam tumpanssari padi sawah+ kedelai yang ditanam pada pematang sawah pada musim tanam I dan II, kemudian pada musim 
tanam III dilanjutkan dengan pola tanam tunggal jagung atau tumpangsari jagung+kedelai (padi sawah+kedelai - padi sawah+kedelai - jagung/ jagung+kedelai). Petani di Kabupaten Malang bagian Selatan dominan menerapkan pola tanam ubi kayu dan jagung yang ditumpangsarikan dengan kedelai (ubi kayu+jagung+kedelai) atau jagung yang ditumpangsarikan dengan kedelai (jagung+kedelai) atau tebu yang ditumpangsarikan dengan kedelai (tebu+kedelai) pada musim tanam I. Pola tanam akan dilanjutkan dengan tumpangsari jagung+kedelai pada musim tanam II jika pada musim tanam I ditanami tumpangsari jagung+kedelai.

Tabel 3. Pola tanam kedelai di kabupaten malang.

\begin{tabular}{|c|c|c|c|c|}
\hline Wilayah & Pola Tanam & $\begin{array}{c}\text { Penerapan } \\
\text { oleh Responden } \\
\text { (petani) }\end{array}$ & $\begin{array}{c}\text { Penerapan oleh } \\
\text { Responden Sejak } \\
\text { Tahun 2018 } \\
\text { (Petani) }\end{array}$ & $\begin{array}{c}\text { Penerapan } \\
\text { Sebelum Tahun } \\
2018 \text { (Petani) }\end{array}$ \\
\hline \multirow{6}{*}{$\begin{array}{l}\text { Kabupaten } \\
\text { Malang } \\
\text { bagian } \\
\text { Selatan }\end{array}$} & $\begin{array}{l}\text { Tumpangsari Ubi } \\
\text { kayu, Jagung dan } \\
\text { Kedelai }\end{array}$ & 6 & 3 & 3 \\
\hline & $\begin{array}{l}\text { Tumpangsari Ubi } \\
\text { Kayu dan Kedelai }\end{array}$ & 3 & 2 & 1 \\
\hline & $\begin{array}{l}\text { Tumpangsari } \\
\text { Jagung dan Kedelai }\end{array}$ & 3 & 1 & 2 \\
\hline & $\begin{array}{l}\text { Tumpangsari Tebu } \\
\text { dan Kedelai }\end{array}$ & 8 & 3 & 5 \\
\hline & Total (petani) & 20 & 9 & 11 \\
\hline & Persentase $(\%)$ & 100 & 45 & 55 \\
\hline \multirow{4}{*}{$\begin{array}{l}\text { Kabupaten } \\
\text { Malang } \\
\text { bagian } \\
\text { Utara }\end{array}$} & $\begin{array}{l}\text { Tumpangsari Padi } \\
\text { Sawah dan } \\
\text { Kedelai*) }\end{array}$ & 17 & 17 & 0 \\
\hline & $\begin{array}{l}\text { Tumpangsari } \\
\text { Jagung dan Kedelai }\end{array}$ & 3 & 3 & 0 \\
\hline & Total (petani) & 20 & 20 & 0 \\
\hline & Persentase (\%) & 100 & 100 & 0 \\
\hline
\end{tabular}

Keterangan : *) Penanaman kedelai pada pematang sawah

Analisis Pergeseran Waktu Tanam Kedelai

Analisis pergeseran waktu tanam kedelai dilakukan berdasarkan pada pola penentuan awal tanam yang diterapkan oleh petani setempat, yaitu berdasarkan pada waktu tanam ubi kayu, tebu atau jagung sebagai komoditas utama yang ditentukan berdasarkan pada awal musim hujan (MH I), sehingga analisis pergeseran waktu tanam kedelai dilakukan berdasarkan pada analisis pergeseran awal musim hujan menggunakan pendekatan sistem dasarian (Gambar 6). Gambar 6 menunjukkan terjadi pergeseran awal musim hujan selama 30 tahun dan rata-rata pergeseran awal musim hujan terjadi tidak secara signifikan yaitu pada kisaran bulan Oktober, November dan Desember. Awal musim hujan yang mengalami perubahan cukup signifikan terjadi pada tahun 2010 dan 2016, memiliki kejadian musim hujan yang lebih panjang daripada tahun-tahun lainnya. Pada tahun 2010, musim kemarau hanya terjadi selama 4 dasarian berturutturut (Juli dasarian ke-1 hingga Agustus dasarian ke-1). Pada tahun 2016, kejadian musim kemarau hanya terjadi selama 4 dasarian berturut-turut (Agustus dasarian ke-1 hingga September dasarian ke-1). 
Pergeseran awal musim hujan lebih lambat yang terjadi selama 30 tahun terakhir yaitu pada tahun 1988, 1999 dan 2006 dimana pada tahun tersebut tidak terjadi awal musim hujan. Pada tahun 1988 awal musim hujan baru mulai terjadi pada bulan Januari dasarian ke-1 pada tahun 1989. Pada tahun 1999 terjadi kejadian kemarau panjang yang dapat dilihat dari tidak adanya awal musim hujan. Kejadian kemarau panjang baru berakhir di bulan November dasarian ke-1 pada tahun 2000. Pada tahun 2006 awal musim hujan baru mulai terjadi pada bulan Febuari dasarian ke-1. Pergeseran awal musim hujan tersebut dapat mempengaruhi pergeseran musim tanam kedelai.

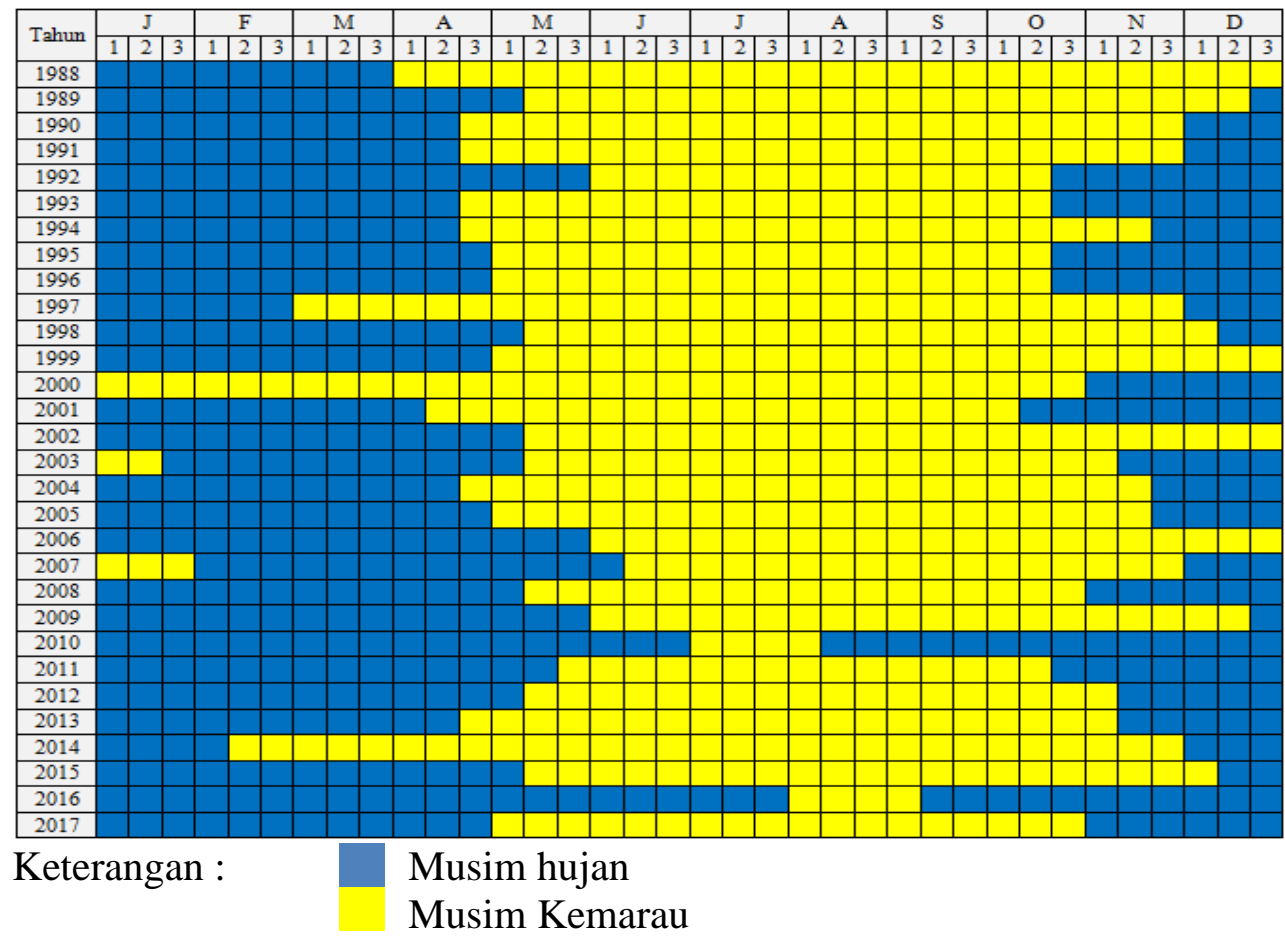

Gambar 6. Analisis pergeseran musim tanam kedelai berdasarkan analisis dasarian pergeseran musim hujan di kabupaten malang bagian selatan selama 30 tahun (1988-2017).

\section{Pendapat Petani Mengenai Perubahan Iklim dan Upaya Adaptasi}

Pengetahuan petani mengenai perubahan iklim dan dampaknya hanya diketahui oleh $42,5 \%$ dan $27,5 \%$ petani, namun setelah dijelaskan melalui pendekatan mengenai definisi perubahan iklim secara sederhana, terdapat $60 \%$ petani berpendapat bahwa perubahan iklim dapat mempengaruhi produksi kedelai serta sebanyak $67,5 \%$ petani berpendapat sudah merasakan adanya perubahan iklim. Sebanyak $87,5 \%$ petani akan menggunakan varietas tahan terhadap perubahan iklim serta sebanyak $95 \%$ petani di Kabupaten Malang bagian Selatan dan $55 \%$ petani di
Kabupaten Malang akan melakukan pergeseran waktu tanam yang disesuaikan dengan awal musim hujan.

Upaya adaptasi terhadap perubahan iklim lain yang dilakukan petani dapat dilihat dari cara petani melakukan pengaturan tata air. Sebanyak $10 \%$ petani di Kecamatan Kalipare dan Pagak yang dominan memiliki jenis lahan kering (tegalan) dan sebanyak $95 \%$ petani di Kecamatan Singosari dan Dau yang dominan memiliki jenis lahan sawah menyatakan akan melakukan pengaturan tata air sebagai upaya adaptasi perubahan iklim. 


\section{PEMBAHASAN}

Kabupaten Malang diketahui telah mengalami perubahan iklim, yang ditunjukkan oleh perubahan suhu, curah hujan dan jumlah hari hujan. Rerata suhu bulanan dan tahunan menyimpang (lebih tinggi atau lebih rendah) dari kondisi ratarata selama 30 tahun terakhir. Suhu udara yang meningkat diduga dipengaruhi oleh fenomena pemanasan global. Febrianti (2018), pemanasan global diduga telah terjadi semenjak awal revolusi industri (akhir abad ke-18 dan awal abad ke-19) yang menyebabkan terjadinya peningkatan suhu udara di permukaan bumi. Rerata peningkatan suhu udara tahunan yang berkisar antara 0,13 hingga $0,27{ }^{\circ} \mathrm{C}$ cenderung menunjukkan peningkatan suhu udara yang lebih tinggi dari peningkatan rata-rata suhu udara yang terjadi di Indonesia. Rerata suhu Kabupaten Malang pada tahun 1988-1997 (baik bulanan dan tahunan) yang lebih rendah dari rata-rata suhu selama 30 tahun terakhir diduga disebabkan oleh adanya letusan gunung merapi sebagai salah satu fenomena alam yang mempengaruhi penurunan suhu ratarata pada tahun 1988-1997. Penurunan suhu secara drastis pada tahun 1900an, 1960an, 1980an dan 1990an terjadi akibat adanya letusan gunung merapi yang sangat besar. Material letusan gunung merapi tersebut selanjutnya mempengaruhi tingkat kejernihan atmosfer. Salah satu faktor yang dapat mempengaruhi jumlah radiasi matahari yang diterima oleh permukaan bumi adalah keadaan awan (Rahim et al., 2016) sehingga naik turunnya suhu di permukaan bumi dipengaruhi oleh besar kecilnya radiasi matahari yang sampai ke permukaan bumi.

Rerata curah hujan bulanan antara Kabupaten Malang bagian Utara dan Selatan cenderung mengalami "tren" fluktuasi perubahan yang berbeda, namun rerata curah hujan bulanan dan tahunan Kabupaten Malang pada periode 2 dan periode 3 diketahui lebih tinggi dari kondisi rata-rata curah hujan bulanan dan tahunannya selama 3 dekade, sedangkan pada periode 1 memiliki rerata curah hujan bulanan dan tahunan yang lebih rendah. Penyebaran dan keragaman curah hujan tersebut dipengaruhi oleh berbagai faktor seperti letak geografi, topografi dan aliran udara atas (Sinurat et al., 2016). Fenomena "El Nino" merupakan anomali iklim yang biasanya diikuti dengan penurunan curah hujan dan peningkatan suhu udara, sedangkan fenomena "La Nina" merupakan anomali iklim yang merangsang terjadinya kenaikan curah hujan di atas curah hujan normal di Indonesia (Irawan, 2006). Kabupaten Malang terdampak kejadian "La Nina" pada periode ke-2 yang ditandai dengan meningkatnya kejadian curah hujan bulanan yang meningkat menjadi 178,26 $\mathrm{mm}$ dengan rerata peningkatan sebesar $16,76 \mathrm{~mm}$ lebih tinggi dari pada periode 1 . Pada periode 3 rerata curah hujan bulanan menurun menjadi 177,12 mm dengan rerata penurunan curah hujan bulanan sebesar $1,14 \mathrm{~mm}$ lebih rendah daripada periode 2 yang artinya pada periode ke-3 Kabupaten Malang terdampak kejadian "El Nino".

Rerata jumlah hari hujan bulanan dan tahunan antara Kabupaten Malang bagian Utara dan Selatan cenderung mengalami "tren" fluktuasi perubahan yang berbeda (Gambar 4). Jumlah hari hujan merupakan salah satu faktor iklim yang ikut mengalami penyimpangan akibat adanya perubahan iklim (Manurung et al., 2015). Perubahan jumlah hari hujan selama 3 periode dapat disebabkan oleh kejadian "El Nino" dan "La Nina".

Antara suhu dan jumlah hari hujan dengan produktivitas kedelai memiliki keeratan hubungan yang rendah (korelasi rendah), sedangkan curah hujan dengan produktivitas kedelai memiliki keeratan hubungan yang sangat rendah (korelasi sangat rendah). Rerata suhu bulanan dan tahunan Kabupaten Malang bagian Selatan (sebagai sentra produksi kedelai) mengalami fluktuasi pada kisaran $25-26$ ${ }^{\circ} \mathrm{C}$. Sumarno dan Mashuri (2016) menyatakan bahwa kisaran suhu rata-rata 
$20-30{ }^{\circ} \mathrm{C}$ merupakan suhu yang sangat sesuai dalam kesesuaian agroklimat kedelai. Rerata curah hujan bulanan 164 - 205 mm.bulan ${ }^{-1}$, menunjukkan bahwa rerata curah hujan bulanan Kabupaten Malang bagian Selatan lebih tinggi daripada rerata curah hujan yang cocok bagi kedelai. Curah hujan yang merata 100 - 150 mm.bulan ${ }^{-1}$ pada dua bulan sejak tanam merupakan kondisi yang baik bagi tanaman kedelai. Jumlah hari hujan merupakan unsur iklim lain yang dapat mempengaruhi produktivitas kedelai selain suhu dan curah hujan. Rerata jumlah hari hujan tahunan yang berkisar antara 139 - 152 hari, lebih tinggi daripada rerata jumlah hari hujan yang sesuai dengan syarat tumbuh kedelai yang berkisar antara 95 - 122 hari.

Keeratan hubungan yang sangat rendah sampai rendah antara suhu, jumlah hari hujan dan curah hujan terhadap produktivitas kedelai diduga disebabkan oleh beberapa faktor, salah satunya adalah keadaan unsur iklim (suhu, hari hujan dan jumlah hari hujan) yang ekstrim selama masa tanam kedelai (Setiawan (2015). Rerata beberapa unsur iklim seperti curah hujan dan hari hujan selama 30 tahun terakhir yang menyimpang dari kesesuaian syarat tumbuh kedelai diduga menyebabkan keeratan hubungan antara unsur iklim dan produktivitas kedelai cenderung rendah.

Suhu merupakan unsur iklim yang memiliki pengaruh nyata terhadap produktivitas kedelai, hal ini diduga disebabkan oleh fluktuasi suhu Kabupaten Malang bagian Selatan yang masih dikategorikan "sangat sesuai" dalam kesesuaian agroklimat kedelai. Sumarno dan Mashuri (2016) menyatakan bahwa kisaran suhu rata-rata $20-30{ }^{\circ} \mathrm{C}$ merupakan kisaran suhu yang sangat sesuai dalam kesesuaian agroklimat kedelai, sedangkan kisaran rerata suhu tahunan dan bulanan Kabupaten Malang bagian Selatan berkisar antara 25 - $26{ }^{\circ} \mathrm{C}$. Utomo (2011) menyatakan bahwa suhu merupakan faktor iklim yang dapat mempengaruhi fotorespirasi tanaman. Peningkatan suhu disekitar tanaman akan berdampak pada konsentrasi $\mathrm{CO}_{2}$ dan $\mathrm{O}_{2}$ di permukaan daun. Prawoto (2007) dalam Utomo (2011) menjelaskan bahwa suhu yang tinggi dan intensitas cahaya yang berlebihan juga mengakibatkan $\mathrm{O}_{2}$ terlepas dari $\mathrm{H}_{2} \mathrm{O}$ sehingga $\mathrm{O}_{2}$ lebih banyak dipermukaan daun dari pada $\mathrm{CO}_{2}$ dan akan menyebabkan terjadinya fotorespirasi. Tanaman kedelai merupakan tanaman $\mathrm{C}_{3}$ yang mengalami fotorespirasi yang berdampak pada hasil bersih fotosintesis yang lebih rendah dari $\mathrm{C}_{4}$ (Ramadhani et al., 2013).

Curah hujan dan hari hujan memiliki pengaruh tidak nyata terhadap produktivitas kedelai (Musyadik dan Nungkat, 2016) diduga disebabkan oleh adanya faktor lain yang dapat mendukung pertumbuhan tanaman seperti kesuburan tanah dan suhu udara (Setyawan et al., 2016).

Perbedaan pemilihan komoditas utama dipengaruhi oleh faktor ekonomi. Pemilihan ubi kayu/tebu/jagung sebagai komoditas utama di lahan kering di Kecamatan Kalipare dan Pagak disebabkan karena petani menilai komoditas tersebut lebih menguntungkan dibandingkan dengan padi, sedangkan pemilihan padi sebagai komoditas utama di lahan sawah di Kecamatan Singosari dan Dau disebabkan karena petani menilai komoditas padi lebih menguntungkan daripada ubi kayu/tebu/jagung. Faktor lain yang berkaitan dengan keputusan petani memilih komoditas tersebut adalah jenis lahan sebagai faktor fisik yang berpengaruh diantara kedua daerah tersebut. Jenis lahan yang dominan di Kecamatan Kalipare dan Pagak adalah lahan kering (tegalan), sedangkan di Kecamatan Singosari dan Dau adalah lahan sawah. Hafif (2014) menyatakan bahwa khusus di lahan kering kebanyakan petani menilai penanaman jagung dan ubi kayu lebih menguntungkan karena komoditas tersebut dinilai petani sebagai komoditas yang paling toleran terhadap kekeringan.

Perubahan iklim merupakan faktor fisik lain yang berpengaruh terhadap pola tanam kedelai. Indikasi adanya pengaruh 
perubahan iklim terhadap pola tanam ditunjukkan dari cara petani menentukan waktu tanam yang disesuaikan dengan awal musim hujan. Indikasi lain dapat dilihat dari cara petani di lahan kering yang menanam jagung+kedelai di musim tanam I dan II, dimana petani akan menanam jagung+kedelai/jagung pada musim tanam III hanya jika musim hujan berlangsung lebih panjang, artinya pola tanam di Kabupaten Malang juga dipengaruhi oleh sebaran musim hujan.

Kebijakan pemerintah daerah Kabupaten Malang merupakan faktor selanjutnya yang mempengaruhi perubahan pola tanam. Perubahan pola tanam pada awal tahun 2018 di Kecamatan Kalipare, Pagak, Singosari dan Dau dipengaruhi oleh adanya kebijakan pemerintah daerah yang memberikan bantuan berupa benih kedelai serta pupuk kandang untuk kedelai sehingga petani bersedia menanam kedelai di kedua daerah tersebut.

Perubahan iklim berpengaruh terhadap waktu tanam kedelai dapat dilihat dari cara petani menentukan waktu tanam kedelai yang disesuaikan dengan waktu tanam ubi kayu/tebu/jagung, dimana waktu tanam komoditas tersebut disesuaikan dengan sebaran musim hujan. Awal tanam ubi kayu/tebu/jagung akan dilakukan ketika awal musim hujan pertama (MH I) bersamaan dengan menanam kedelai yang ditumpangsarikan dengan komoditas utama (ubi kayu/tebu/jagung). Waktu tanam II yaitu pada musim hujan kedua (MH II) akan dilanjutkan dengan menanam jagung dan kedelai jika pada musim tanam I ditanam jagung sebagai komoditas utama. Musim tanam III akan dilakukan hanya ketika petani merasa musim hujan berlangsung lebih panjang pada lahan yang di musim tanam I dan II ditanami jagung sebagai komoditas utama, sedangkan jika musim hujan berlangsung lebih pendek, maka petani tidak akan menanam pada musim tanam III jika pada lahan yang di musim tanam I dan II ditanami jagung sebagai komoditas utama. Berdasarkan informasi tersebut maka dapat diketahui awal musim hujan (AMH) dan sebaran musim hujan berpengaruh pada waktu tanam kedelai.

Keuntungan perubahan pola tanam yang dilakukan oleh petani adalah untuk pemanfaatan lahan dengan komoditas utama yang memiliki umur panen yang panjang (ubi kayu dan tebu) serta pemanfaatan lahan yang lebih optimal di lahan sawah. Ubi kayu memiliki umur panen antara 8-12 bulan (Sundari, 2010), begitupun tebu dengan umur panen antara 8-12 bulan (Indrawanto et al., 2010). Keuntungan penerapan sistem tumpangsari kacang-kacangan seperti kedelai dengan tanaman ubi kayu yaitu petani lebih cepat mendapat hasil tunai dari panen kedelai sementara menunggu tanaman ubi kayu atau komoditas lain yang berumur panen panjang dapat dipanen (Musaddad, 2008). Faktor yang dapat mempengaruhi pola tanam yang merupakan salah satu sub sistem dari budidaya tanaman yaitu faktor fisik yang meliputi faktor iklim (cahaya matahari, curah hujan dan suhu), dan faktor tanah sebagai tempat tumbuh (kesuburan tanah, kemiringan lahan dan sistem drainase), faktor manusia yang meliputi faktor sosial yang berasal dari budaya, kepercayaan, faktor ekonomi yang sangat ditentukan oleh harga yang dipengaruhi oleh situasi pasar serta dan kebijakan pemerintah (Guritno, 2011)

Pergeseran awal musim tanam kedelai di Kabupaten Malang bagian Selatan disebabkan karena adanya pergeseran awal musim hujan yang telah terjadi. Penentuan waktu tanam yang disesuaikan dengan awal musim hujan disebabkan karena karakteristik lahan kering (tegalan) dengan ketersediaan airnya tergantung pada curah hujan. Winardi (2014) menyatakan bahwa penentuan pola tanam kedelai didasarkan atas tipe lahan, curah hujan atau persediaan air dan musim dimana penanaman kedelai di lahan kering/tadah hujan dapat dilakukan pada awal musim hujan (November-Februari). Di Kabupaten Malang bagian Selatan telah terjadi pergeseran awal musim hujan 
selama 30 tahun terakhir pada setiap tahunnya. Pergeseran awal musim hujan tersebut selanjutnya dapat mempengaruhi penentuan waktu tanam kedelai di Kecamatan Kalipare dan Pagak.

Pengetahuan mengenai perubahan iklim serta dampaknya terhadap produksi dan produktivitas tanaman merupakan hal penting. Pengetahuan dan kemampuan adaptasi petani akan berpengaruh pada bentuk tindakan adaptasi terhadap perubahan iklim yang dilakukan. Artinya perlu adanya upaya penyampaian informasi mengenai perubahan iklim kepada petani serta upaya untuk memfasilitasi petani dalam mengadaptasi upaya penyesuaian usaha tani terhadap perubahan iklim untuk menjaga produktivitas tanaman yang optimal (Kurniawati, 2012).

Upaya adaptasi tata air yang rendah $(10 \%)$ serta pergeseran waktu tanam yang tinggi (95\%) disebabkan karena lahan kering (tegalan) yang hanya bergantung pada air hujan untuk memenuhi kebutuhan air sehingga sulit untuk melakukan sistem tata air. Hernowo (2018) menjelaskan bahwa secara umum lahan kering sebagai salah satu tipologi lahan usahatani memiliki beberapa tipikal yang berhubungan dengan ketersediaan air bagi tanaman antara lain memiliki sumberdaya air yang terbatas, mengandalkan air hujan, memiliki air tanah yang relatif dalam dan hilangnya air relatif cepat (fazt-drain).

Upaya adaptasi lain yang dapat dilakukan adalah penggunaan varietas yang tahan terhadap perubahan iklim $(87,5 \%)$ Thamrin et al. (2013) adaptasi pengelolaan pertanian perlu dilakukan terhadap perubahan iklim yang terjadi, salah satunya dengan penggunaan teknologi yang menghasilkan varietas baru yang mampu beradaptasi dengan perubahan iklim. Perubahan iklim dapat berpengaruh terhadap kejadian musim hujan yang singkat, untuk beradaptasi dengan keadaan tersebut, perlu adanya upaya penggunaan varietas yang berumur genjah untuk menjaga produktivitas tanaman tetap optimal. Perubahan iklim global juga dapat mempengaruhi perilaku serangga hama dalam beradaptasi dengan lingkungannya (Iswanto et al., 2015) seperti berdampak pada penyebaran penyakit, mempengaruhi siklus hidup serangga vektor dan lain sebagainya (Ladja dan Widiarta, 2012), sehingga tidak hanya varietas yang tahan terhadap cekaman abiotik yang hanya perlu dilakukan, tetapi juga perlu adanya upaya perakitan dan penggunaan varietas yang tahan terhadap hama penyakit dalam upaya adaptasi perubahan iklim.

\section{KESIMPULAN}

Perubahan iklim di Kabupaten Malang telah terjadi selama kurun waktu 30 tahun terakhir (1988-2017), yang ditunjukkan oleh perubahan rerata suhu, curah hujan dan hari hujan. Korelasi antara suhu dengan produktivitas kedelai memiliki keeratan hubungan yang "rendah" $(\mathrm{r}=$ 0,31 ) dan suhu berpengaruh nyata terhadap produktivitas kedelai. Korelasi antara jumlah hari hujan dengan produktivitas kedelai memiliki keeratan hubungan yang "rendah" $(r=-0,21)$, sedangkan curah hujan memiliki keeratan hubungan yang "sangat rendah" $(\mathrm{r}=-0,18)$. Pola tanam kedelai tidak dipengaruhi oleh perubahan iklim, tetapi dipengaruhi oleh jenis lahan (faktor fisik), serta faktor ekonomi dan kebijakan pemerintah daerah. Waktu tanam kedelai (maju mundurnya waktu tanam) dipengaruhi oleh pergeseran musim hujan sebagai salah satu dampak dari perubahan iklim.

\section{DAFTAR PUSTAKA}

Anonymous. 2016. Outlook Komoditas Pertanian Sub Sektor Pangan: Kedelai. Pusat Data dan Sistem Informasi Pertanian. Jakarta. p 48.

Apriyana Y, Susanti E, Suciantini, Ramadhani F, Surmaini E. 2016. Analisis Dampak Perubahan Iklim terhadap Produksi Tanaman Pangan pada Lahan Kering dan Rancang Bangun Sistem Informasinya. $J$. 
Informatika Pertanian. 25 (1): 6980.

Febrianti N. 2018. Hubungan Pemanasan Global dengan Kondisi Suhu Udara dan Curah Hujan di Indonesia. LAPAN. Bandung. p 299.

Guritno B. 2011. Pola Tanam di Lahan Kering. Malang: UB Press. p 5.

Hafif B. 2014. Dampak Perubahan Iklim terhadap Pola Pengelolaan Lahan Pertanian di Lampung. Seminar Nasional BKS PTN Barat. Bandar Lampung. p 19-21.

Hermanto. 2011. Pedoman Umum Adaptasi Perubahan Iklim Sektor Pertanian. Badan Penelitian dan Pengembangan Pertanian. Jakarta. P 4.

Hernowo B. 2018. Pengembangan Sumberdaya Lahan di Kawasan Pedesaan. Direktorat Pemukiman dan Perumahan. Jakarta. p 1.

Indrawanto C, Purwono, Siswanto, Syakir, M, Rumini W. 2010. Budidaya dan Pasca Penen Tebu. Eska Media. p 11.

Irawan B. 2006. Fenomena Anomali Iklim El Nino dan La Nina: Kecenderungan Jangka Panjang dan Pengaruhnya terhadap Produksi Pangan. J. Forum Penelitian Agro Ekonomi. 24 (1): 28-45.

Iswanto E H, Susanto U, Jamil A. 2015. Perkembangan dan Tantangan Perakitan Varietas Tahan dalam Pengendalian Wereng Coklat Indonesia. J. Litbang Pertanian. 34(4): 187-193.

Kurniawati F. 2012. Pengetahuan dan Adaptasi Petani Sayuran terhadap Perubahan Iklim. Tesis. Universitas Padjajaran. Bandung.

Ladja F T, Widiarta I N. 2012. Varietas Unggul Baru Padi untuk Mengantisipasi Penyakit Tungro. $J$. IPTEK Tanaman Pangan. 7(1): 1824.

Laimeheriwa S. 2014. Trend Analyse of Rainfall Change at Three Regions with Different Rain Pattern in
Maluku Province. Jurnal Budidaya Pertanian. 10: 71-78.

Manurung MT, Irsal, Haryati. 2015. Pengaruh Curah Hujan dan Hari Hujan terhadap Produksi Tanaman Karet (Hevea brasiliensis MuellArg.) Umur 6, 10 dan 14 Tahun pada PT. Bridgestone Sumatera Rubber Estate Dolok Merangir. J. Online Agroekoteknologi. 3(2): 564573.

Meridian A H, Mancayo AS, Wijaya A., Nugroho B, Hartati C, Wadji F, Gamin, Indrarto GB, Prayitno $\mathrm{H}$. 2015. Media Informasi Seputar Hutan Indonesia. Forest Watch Indonesia. Bogor. $\mathrm{p} 6$.

Musaddad A. 2008. Teknologi Produksi Kedelai, Kacang Tanah, Kacang Hijau, Ubi Kayu dan Ubi Jalar. Balai Penelitian Tanaman Kacangkacangan dan Umbi-umbian. Malang. p 2-19.

Musyadik, Nungkat P. 2016. Pengaruh Curah Hujan Terhadap Produksi Kedelai di Kabupaten Konawe Selatan. Prosiding Hasil Seminar Penelitian Tanaman Aneka Kacang dan Umbi. p 699-700.

Pawitro U. 2016. Pemanasan Global (Protokol Kyoto dan Penerapan Kaidah Arsitektur Ekologis). Jurnal Ilmiah KORPRI Kopertis Wilayah IV. 1(1): 1-11.

Rahim R, Asniawaty, Martosenjoyo T, Amin S, Hiromi R. 2016. Karakteristik Data Temperatur Udara dan Kenyamanan Termal di Makassar. Prosiding Temu Ilmiah IPLBI. Universitas Hasanuddin. Makassar.

Ramadhani F, Putri L A P, Hasyim H. 2013. Evaluasi Karakteristik Beberapa Varietas Kedelai (Glycine $\max$ L. Merill) Hasil Mutasi Kolkisin M2 pada Kondisi Naungan. $\quad J$. Online Agroekoteknologi. 1(3): 453-466.

Ramlan M. 2002. Pemanasan Global. J. Teknologi Lingkungan. 3(1): 30-32. 
Ruminta. 2015. Dampak Perubahan Iklim pada Produksi Apel di Batu Malang. J. Kultivasi. 14 (2): 42-48.

Setiawan K. 2015. Pengaruh Curah Hujan terhadap Produktivitas Pangan di Jawa Timur. Skripsi. Sekolah Tinggi Ilmu Meteorologi dan Geofisika (STMKG). Tangerang Selatan.

Setyawan E, Subantoro R, Prabowo R. 2016. Analisis Faktor yang Berpengaruh Terhadap Produksi Karet di PT. Perkebunan Nusantara IX Kebun Sukamangli Kabupaten Kendal. Mediagro. 12 (1): 35-44.

Setyawardhana H, Susandi A. 2015. Proyeksi Awal Musim di Jawa Berbasis Hasil Downscaling Conformal Cubic Atmospheric Model (CCAM). J. Sains Dirgantara. 13(1): 1-13.

Sinurat N, Sugianto, Harjupa W. 2016. Analisa Arah Angin Terhadap Curah Hujan Menggunakan Equatorial Atmosphere Radar (EAR) dan Optical Rain Gauge (ORG) di Atas Kototabang Sumatera Barat. Universitas Riau. Riau.

Sipayung S B. 2005. Dampak Variabilitas Iklim terhadap Produksi Pangan di Sumatera. J. Sains Dirgantara 2(2): 111-126.

Soeparno H, Pasandaran E, Syarwani M, Dariah A, Pasaribu S M, Saad N S. (Eds). 2013. Politik Pembangunan Pertanian Menghadapi Perubahan Iklim. Jakarta: IAARD Press. 509 pp.
Sumarno, Manshuri A G. 2016. Persyaratan Tumbuh dan Wilayah Produksi Kedelai Indonesia. Balai Penelitian Tanaman Kacang-kacangan dan Umbi-umbian. Malang. 30pp.

Sundari T. 2010. Petunjuk Teknis Pengenalan Varietas Unggul dan Teknik Budidaya Ubi Kayu. Balai Penelitian Kacang Kacangan dan Umbi-umbian. Malang. p 11.

Utina R. 2015. Pemanasan Global (Dampak dan Upaya Meminimalisirnya). Gorontalo: Universitas Negeri Gorontalo Press.

Thamrin M, Ruchjaniningsih, Nappu M B. 2013. Perubahan Iklim dan Antisipasi Teknologi dalam Pengelolaan Tanaman Jagung Lahan Kering. Seminar Nasional Serelia. Balai Pengkajian Teknologi Pertanian Sulawesi Selatan. Makassar.

Tosiani A. 2015. Buku Kegiatan Serapan dan Emisi Karbon. Direktur Inventarisasi dan Pemantauan Sumberdaya Hutan. Jakarta. p 12.

Utomo S. B. 2011. Dinamika Suhu Udara Siang-Malam terhadap Fotorespirasi Fase Generatif Kopi Robusta dibawah Naungan yang Berbeda pada Sistem Agroforestri. Skripsi. Universitas Jember. Jember. $\mathrm{p} 1$.

Winardi. 2014. Prospek Budidaya Kedelai pada Lahan Sawah Tadah Hujan dan Sawah Irigasi Sederhana untuk Peningkatan Produksi Kedelai di Indonesia. Jurnal Agritech. 16(2):89-97. 